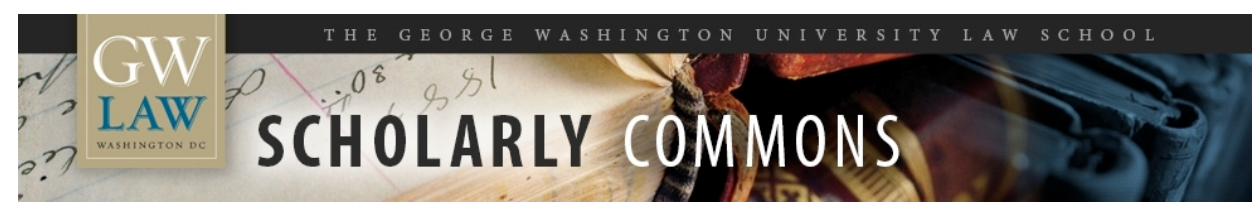

\title{
Litigation Finance and the Problem of Frivolous Litigation
}

Michael B. Abramowicz

George Washington University Law School, abramowicz@law.gwu.edu

Follow this and additional works at: https://scholarship.law.gwu.edu/faculty_publications

Part of the Law Commons

\section{Recommended Citation}

Abramowicz, Michael B., Litigation Finance and the Problem of Frivolous Litigation (2014). Litigation Finance and the Problem of Frivolous Litigation, 63 DePaul L. Rev. 195 (2014) (symposium contribution). ; GWU Law School Public Law Research Paper No. 2019-18; GWU Legal Studies Research Paper No. 2019-18. Available at SSRN: https://ssrn.com/abstract $=3366637$

This Article is brought to you for free and open access by the Faculty Scholarship at Scholarly Commons. It has been accepted for inclusion in GW Law Faculty Publications \& Other Works by an authorized administrator of Scholarly Commons. For more information, please contact spagel@law.gwu.edu. 


\title{
LITIGATION FINANCE AND THE PROBLEM OF FRIVOLOUS LITIGATION
}

\author{
Michael Abramowicz*
}

\begin{abstract}
Litigation finance companies have some incentives to screen plaintiffs applying for financing based on the strength of their claims, but a company may still have incentives to provide financing when the probability that a plaintiff would prevail at litigation is low. The result is that litigation finance may facilitate both meritorious and nonmeritorious claims. This Article argues that fee limitation rules for litigation finance companies can improve their incentives to select only relatively high probability cases, thus enhancing the normative case for states to enact legal reforms allowing litigation finance. A simple version of the rule, which will work if a case is sure to go to trial, allows a successful plaintiff to return no more than the amount borrowed and then the same amount again, plus ordinary interest. This rule will encourage finance companies to lend only where a plaintiff's probability of winning is expected to be greater than $50 \%$, although the rule can be altered to target lower probability thresholds. The Article also describes alterations to the rule to accommodate the possibility of settlement, cases in which damages are disputed, where injunctive relief is at issue, where financing is provided in installments, and where only a portion of the plaintiff's expenses are paid by litigation finance companies. Should fee limitation rules become established in the fee limitation context, they also might be extended as a vehicle of tort reform. A requirement that plaintiffs and defendants fund some portion of their litigation costs through litigation finance can reduce frivolous suits and frivolous defenses of meritorious suits and may have advantages over other mechanisms, such as fee-shifting rules.
\end{abstract}

\section{INTRODUCTION}

Recently, litigation finance companies and arrangements have become more commonplace in both the United States and abroad. ${ }^{1}$ Typ-

* Professor of Law, George Washington University. I am grateful to the Searle Center on Law, Regulation, and Economic Growth for funding this research, and to participants in a Searle Center Roundtable for helpful comments.

1. See, e.g., David S. Abrams \& Daniel L. Chen, A Market for Justice: A First Empirical Look at Third Party Litigation Funding, 15 U. PA. J. Bus. L. 1075 (2013) (documenting the recent increase in litigation finance in Australia); Susan Lorde Martin, Litigation Financing: Another Subprime Industry that Has a Place in the United States Market, 53 Vill. L. Rev. 83 (2008) (discussing litigation finance in the United States); Andrew Hill, Money for Smart Suits, FIN. 
ically, a litigation finance company will give a plaintiff who otherwise might not be able to afford a lawsuit the funds needed to cover legal expenses. Loans are nonrecourse; if the plaintiff loses the lawsuit, the loan is forgiven. ${ }^{2}$ Interest rates on such loans are accordingly well in excess of typical market rates, but such an arrangement may be beneficial to plaintiffs who do not have enough cash on hand to finance a lawsuit and who either cannot obtain funds through traditional loan sources or do not want to risk the possibility of facing a large debt if the lawsuit fails. The social welfare case for litigation finance is simple. Litigation finance is effectively a type of law firm finance, a means of enabling law firms to represent clients whom they otherwise might not be able to defend. Such financing enables liquidity-constrained plaintiffs to bring more cases and to prosecute cases more effectively. ${ }^{3}$ Increased funding for litigation should thus reduce legal error and help achieve the legal system's goals, including both compensation and deterrence of negligent or wrongful acts.

Litigation finance, however, at times might be used to fund nonmeritorious cases. ${ }^{4}$ It might seem that plaintiffs have no incentive to bring cases that would likely lose, but a plaintiff might have some probability of prevailing on a nonmeritorious claim. The possibility of legal error thus suggests a need to balance the benefits of legal finance (reduction in false negatives, where meritorious claims are lost because of lack of financing) with its costs (increase in false positives, where nonmeritorious claims prevail or receive a nuisance settlement). When evaluating procedure, it is impractical to inquire as to the correctness of substantive law, and yet it would be foolish to pretend that the result actually achieved in a particular case is always the correct one. A simple yet valuable measure of a hypothetical claim's

Times, Jan. 5, 2007, at 18 (discussing the rise of litigation finance in the United Kingdom). For a history of the litigation finance industry in the United States, see Mariel Rodak, Comment, It's About Time: A Systems Thinking Analysis of the Litigation Finance Industry and Its Effect on Settlement, 155 U. PA. L. Rev. 503, 505-08 (2006).

2. Courtney R. Barksdale, Note, All That Glitters Isn't Gold: Analyzing the Costs and Benefits of Litigation Finance, 26 Rev. Litig. 707, 708-09, 709 n.8 (2007) (examining the repayment provisions of typical litigation finance contracts).

3. See, e.g., Lauren J. Grous, Note, Causes of Action for Sale: The New Trend of Legal Gambling, 61 U. Miami L. Rev. 203, 204 (2006) (characterizing the litigation finance industry as an antidote for situations in which "a plaintiff with a strong cause of action may lack the finances to either pursue the claim or to pay medical bills and other living expenses during the litigation's pendency").

4. For previous arguments to this effect, see Jeremy Kidd, To Fund or Not To Fund: The Need for Second-Best Solutions to the Litigation-Finance Dilemma, 8 J.L. Econ. \& PoL'y 613, 627-29 (2012); Geoffrey J. Lysaught \& D. Scott Hazelgrove, Economic Implications of Third-Party Litigation Financing on the U.S. Civil Justice System, 8 J.L. Econ. \& PoL'y 645, 662-65 (2012); Rodak, supra note 1, 518-19. 
merit is the percentage of judges or juries that would find for the plaintiff on the claim. So, to evaluate litigation finance, we should assess the extent to which the new claims that it enables are claims that usually would succeed, meaning a majority of courts in the jurisdiction would find for the plaintiff, or claims that usually would fail, meaning a majority of courts would conclude that the plaintiff should not recover.

It might seem that litigation finance should score well under this criterion. Because loans are nonrecourse, lenders have some incentive to screen cases. ${ }^{5}$ If the probability of success is sufficiently low, lenders will not finance a case. Lenders, however, still might finance some low-probability cases if the expected recovery will be great enough to pay off the loan with a sufficient return. Because most cases settle, ${ }^{6}$ as both sides seek to avoid legal expenses, lenders might finance even cases that would have only a small chance of succeeding if tried. Such settlements may be for relatively low dollar amounts, but nonetheless should be given some weight as false positives in the overall social calculus. Meanwhile, the universe of potential cases may include many more low-probability cases than high-probability ones. ${ }^{7}$ For any given level of damages, a lawyer may be able to find a large number of cases with a low probability of winning for each single case with at least a $50 \%$ chance of winning. Finally, because contingency fee arrangements already exist to help plaintiffs with limited means and serve a similar screening function, the additional cases enabled by litigation finance are those that contingency fee lawyers would not accept and may tend to be disproportionately weak. Litigation finance is a form of finance that enables law firms to take cases that they otherwise would reject, thus the relevant cases are the marginal ones that a law firm would not take on contingency.

5. See Abrams \& Chen, supra note 1, at 1088 (noting that Australian litigation finance companies claim to take cases only "where they estimate the probability of winning a successful judgment or settlement to be large," from at least $50 \%$ to at least $95 \%$ depending on the firm). This quotation reveals that firms are interested in cases that will produce a successful judgment or settlement, not necessarily those cases that, if tried, would be likely to yield a judgment.

6. See generally Marc Galanter \& Mia Cahill, "Most Cases Settle": Judicial Promotion and Regulation of Settlements, 46 STAN. L. Rev. 1339 (1994).

7. It is difficult to measure the distribution, but Robert Gertner offers a theoretical model showing that "[1]itigated cases differ from the underlying distribution of disputes in that they are less likely to be successful than a randomly chosen dispute and damages are likely to be higher than in a randomly chosen dispute." Robert H. Gertner, Asymmetric Information, Uncertainty, and Selection Bias in Litigation, 1993 U. Chi. L. Sch. Roundtable 75, 90-91. This is consistent with the existence of disputes that have a small probability of producing high damages, precisely the disputes that a litigation finance mechanism might seek to exclude. 
The net social welfare effects of litigation finance are indeterminate. Theory alone cannot tell us how many false positives litigation finance will enable, let alone whether the relatively small cost of settlements in many such cases outweighs the benefit of reduced false negatives. Litigation finance provides a screening function that will tend to reduce false positives relative to a hypothetical world in which all plaintiffs have sufficient liquidity to bring their own lawsuits. It would be difficult to measure empirically the overall quality of lawsuits financed by litigation finance companies, both because it is difficult to determine whether such cases would still have been brought absent litigation finance and because measuring lawsuit quality is challenging when many lawsuits settle.

It should be possible, however, to improve the incentives of litigation finance companies not to finance low-probability suits by enacting rules that will affect their financial return. Indeed, those who are critical of litigation finance on the basis that it can spur frivolous litigation should recognize that, in fact, litigation finance presents an opportunity. Because litigation finance companies will necessarily perform some screening on the quality of lawsuits they fund, rules can be devised that will tend to improve the incentives of companies to support lawsuits they truly believe are meritorious while rejecting nonmeritorious ones. A variety of mechanisms seeking to achieve similar effects already exist and operate directly on litigants. These mechanisms include sanctions for frivolous suits ${ }^{8}$ and fee-shifting rules. ${ }^{9}$ However, designing such mechanisms to produce optimal incentives is not straightforward, even for liquid, risk-neutral plaintiffs, ${ }^{10}$ and it may be particularly difficult for such mechanisms to optimize the incentives of plaintiffs who might not have the funds to pay sanc-

8. See, e.g., FED. R. Civ. P. 11(b)-(c) (allowing a court to impose sanctions on an attorney, law firm, or party where "the claims, defenses, and other legal contentions are [not] warranted by existing law or by a nonfrivolous argument for extending, modifying, or reversing existing law or for establishing new law," or where "the factual contentions [do not] have evidentiary support").

9. Analyses of fee-shifting rules include Ephraim Fischbach \& William McLauchlan, ReverseCost-Shifting: A New Proposal for Allocating Legal Expenses, 32 J. Marshall L. Rev. 35 (1998); Gregory E. Maggs \& Michael D. Weiss, Progress on Attorney's Fees: Expanding the "Loser Pays" Rule in Texas, 30 Hous. L. Rev. 1915 (1994); Walter Olson \& David Bernstein, Loser-Pays: Where Next?, 55 MD. L. REv. 1161 (1996); Thomas D. Rowe, Jr., The Legal Theory of Attorney Fee Shifting: A Critical Overview, 1982 Duke L.J. 651; Eric Talley, Liability-Based Fee-Shifting Rules and Settlement Mechanisms Under Incomplete Information, 71 CHI.-KENT L. Rev. 461 (1995); Matthew J. Wilson, Failed Attempt to Undermine the Third Wave: Attorney Fee Shifting Movement in Japan, 19 EMORy InT'L L. Rev. 1457 (2005).

10. The analysis in this Article generally assumes risk-neutrality for simplicity of analysis. A behavioral economics analysis suggests that in relatively low-probability cases, plaintiffs in fact tend to be risk-seeking and defendants tend to be risk-averse. See Chris Guthrie, Framing Frivolous Litigation: A Psychological Theory, 67 U. CHI. L. Rev. 163 (2000). 
tions or opponents' legal expenses. A requirement that plaintiffs put up a bond may arbitrarily screen out good cases if the plaintiffs have no access to litigation finance. It may be easier to design mechanisms that affect the returns of the lenders, so that their screening will be closely aligned with social interest. This Article describes such a mechanism, along with a number of variations, and identifies its advantages relative to alternatives.

The core mechanism consists of a fee limitation, specifying the maximum amount that the lender can receive if the plaintiff prevails. ${ }^{11}$ In addition to receiving back the principal that it has lent, the lender, in the most basic case, can receive the plaintiff's reasonable legal expenses $^{12}$ once more plus a regulated ordinary interest rate on the money lent. The intuition underlying this general approach is that what the lender can receive as profit when the plaintiff wins should be tailored to the amount that the lender puts at risk. It is straightforward to show that this approach will give the litigation finance company the incentive to lend money only when it believes that the plaintiff is more likely than not to prevail in the litigation, if the case is certain to be tried. This approach could be mandated by state law or voluntarily adopted by industry in an attempt to forestall state regulation, for example through the American Legal Finance Association, which has published lists of industry "best practices." 13

11. Susan Martin discusses the possibility of restricting fees to a reasonable rate of return, as is the practice with various regulated industries. See Martin, supra note 1, at 102-04. Such an approach might be appropriate if there is concern that fees will be systematically excessive. This Article, however, advances a fee limitation out of concern for the interests of defendants and derivatively of society generally, and seeks to develop a mechanism that can improve litigation finance companies' incentives in particular cases.

12. This refers only to the legal expenditures funded by the litigation finance company. Often, litigation finance companies work with plaintiffs who will pay most of their expenses through a contingency fee arrangement. See, e.g., Grous, supra note 3, at 209 (citing Approval Factors, OASIS LEGAL FIN., https://www.oasislegal.com/legal_finance_services/lawsuit_funding_approval_ factors (last visited Nov. 11, 2013) (describing one litigation finance company that requires its clients to work with contingency fee lawyers). Because the contingency fee that the lawyer receives from the client's winnings is not money put up by a litigation finance company, this money should not increase the maximum amount that the litigation finance company can receive.

13. See Industry Best Practices-ALFA's Code of Conduct, Am. Legal Fin. Ass'n, http:// www.americanlegalfin.com/IndustryBestPractices.asp (last visited Nov. 11, 2013) (listing six best practices). One of the best practices seems designed to allay concerns that litigation finance companies might fund low-probability litigation and derive settlements by credibly threatening to take such cases to trial. See id. ("Each member agrees that they will not intentionally overfund a case in relation to their perceived value of the case at the time of such advance."). This requirement is quite vague, however, especially because it does not make clear what constitutes over-funding relative to perceived value. For a discussion of ALFA self-regulation, see Grous, supra note 3, at 233-36. Grous notes that so far, "ALFA's goals and mission fail to make lowering excessive interest fees a priority." Id. at 235. 
This approach alone, however, will not be sufficient to screen claims that the litigation finance company believes are low quality, for the same reason that contingency fee screening may be inadequate. Even if a lender would not lend when sure that a case would go to trial, the lender might well lend because of the possibility or likelihood that the case would settle well before trial. If the lender expects the plaintiff to be able to achieve a quick settlement, then in effect the lender anticipates a very high probability that the plaintiff will recover something through settlement, even if there is a relatively low probability that the plaintiff would recover at trial. An ideal mechanism would allow the lender to recover only to the extent that the plaintiff would be able to prevail at trial.

This adjustment is straightforward if the amount of damages the plaintiff would receive if liability were found at trial is known. The fee limitation formula must include an adjustment for partial recoveries by the plaintiff, including partial recoveries achieved through settlement. For example, if the plaintiff receives only one-tenth of the total damages, then the maximum amount that the plaintiff could pay back to the lender would be only two-tenths of the amount lent, resulting in a loss for the lender. To implement this in practice, however, requires an assessment of the damages that the plaintiff would receive if successful at trial, which compared with the damages actually received produces a measure of the plaintiff's degree of success. A simple approach is to request that the plaintiff self-assess the damages that would be awarded if the plaintiff wins, and allow the defendant to agree to this damages figure should the plaintiff win. The plaintiff and lender will not want to select too low a number, lest the defendant agree to that damages level, or too high a number, lest the fee limitation be too severe.

It is also possible to combine the fee limitation approach with a feeshifting requirement. For example, a litigation finance company might be required to pay the reasonable legal expenses of the defendant if a lawsuit that it funds is unsuccessful, or to the extent that it is unsuccessful in the event of a settlement. Because the potential fee-shifting increases the downside for the litigation finance company in the event that the plaintiff loses, it should lead to a corresponding relaxation of the fee limitation requirement. An advantage of combining the fee limitation with fee-shifting is that it reduces the danger that the parties might collude to evade a fee limitation requirement if the parties should reach a settlement before the production of a reliable estimate of the damages that the plaintiff would receive if liability was found. Such incentives to collude could exist because litigation finance com- 
panies, as repeat players, might seek to establish reputations for going to trial even when it is not within their economic interest, if the defendant fails to agree to an early nuisance settlement. The fee-shifting component will increase the defendant's incentive and ability to resist any such efforts.

This Article proceeds as follows. Part II analyzes unregulated litigation finance and compares its incentives to those provided by contingency fee arrangements. It shows that although litigation finance provides some incentive for lenders to choose high-probability cases, there may also be incentives to fund relatively low-probability cases. Part III describes the basic mechanism. It details how to calculate the fee limitation for any desired probability threshold below which it is deemed desirable to encourage litigation finance companies to screen claims, both with and without fee-shifting. Part IV elaborates on variations and extensions to the basic approach, including how it could be used in disputes over damages rather than liability, in suits in which there are one or more claims for injunctive relief, where the litigation finance company provides financing in installments, and where only some of the plaintiff's financing is to be provided by a litigation finance company. Part IV also evaluates the settlement incentives produced by the fee limitation rule and its variations, noting that it should generally increase rather than decrease the plaintiff's incentives to settle cases. Finally, it considers the possibility that if the fee limitation approach successfully induces companies to screen low-probability cases, partial litigation finance should be required as an alternative to other mechanisms for discouraging frivolous litigation. Part V concludes.

\section{A Model of Contingency Fees and Litigation Finance}

This Part offers a brief explanation of why low-probability lawsuits should be seen as problematic, and why the screening that lawyers conduct before agreeing to contingency fee cases and that litigation finance companies perform before extending nonrecourse loans still may not provide socially adequate incentives to block low-probability lawsuits. If legal expenses were entirely predictable then a very simple mechanism, a limit on the fee recovery to the amount lent plus an adjustment for the time value of money, could discourage litigation finance companies from supporting low-probability cases. But litigation expenses are not entirely predictable, particularly because while most cases settle, a few cases will go to trial. The result is that this simple fee limitation will not be effective in screening low-probability lawsuits. 


\section{A. The Problem with Low-Probability Lawsuits}

The economic literature on frivolous litigation sometimes equates frivolousness with a case having a negative expected value for the plaintiff if it were tried. ${ }^{14}$ This definition has been criticized, however. ${ }^{15}$ A meritorious lawsuit might have a negative expected value merely because it would be expensive to try, but it might be both privately and socially worthwhile, given the likelihood of settlement. On the other hand, a lawsuit that the vast majority of judges and juries would reject might still have positive expected value, if a rogue judge or idiosyncratic jury on occasion might grant a significant damages award. The traditional definition of "frivolousness" may follow naturally as a matter of semantics. For example, it might seem odd to say that a claim with a $25 \%$ chance of winning is frivolous, because a $25 \%$ chance is nontrivial. Nonetheless, such cases may be normatively undesirable, because $75 \%$ of judges would reject the plaintiff's claim. This Article's concern is thus with cases in which the plaintiff is expected to have a low probability of winning. Given the semantic concern, the Article will avoid applying the "frivolous" label to such cases, ${ }^{16}$ but the normative premise is that it is generally beneficial to discourage plaintiffs from pursuing cases that the defendants will probably win, or at least those that the defendants have a very high probability of winning. ${ }^{17}$

14. See, e.g., Peter H. Huang, Lawsuit Abandonment Options in Possibly Frivolous Litigation Games, 23 Rev. Litig. 47, 59 (2004) (noting that a relatively "inclusive definition of frivolous litigation also includes negative-expected-value lawsuits"). See generally Lucian Arye Bebchuk, Suits with Negative Expected Value, in 3 The New Palgrave Dictionary of Economics and THE LAW 551 (Peter Newman ed., 1998) (providing an overview of the economics of negativeexpected-value suits).

15. See, e.g., Robert G. Bone, Modeling Frivolous Suits, 145 U. PA. L. REv. 519, 530 (1997) (offering a simple example that illustrates the problem).

16. Bone rejects the notion that frivolousness should be equated with low probability of success, because a case with a high probability of success should count as frivolous if the party knows that there is only a small chance that the defendant is in fact liable. Id. at 530-31. This helps explain why this Article will generally avoid the "frivolous" label. Any attempt, however, to define frivolousness to include cases in which the plaintiff will generally win even though the plaintiff should not win seems unlikely to be able to generate mechanisms for combating such frivolousness, because the legal system by definition will be unable to identify those cases.

17. For a previous analysis of the case against "long shot" cases, see Charles M. Yablon, The Good, the Bad, and the Frivolous Case: An Essay on Probability and Rule 11, 44 UCLA L. Rev. 65, 99-101 (1996). Yablon also offers some arguments in favor of long shot cases. See id. at 101-04. One limitation of his analysis lies in the statement, "[w]hether a losing case is deterred or is filed and ultimately lost, the 'right' legal result occurs. No injustice has been done ...." Id. at 101. This ignores two possibilities: first, long shot cases that win even though most courts would reject them; and second, long shot cases that produce settlements where the defendant ideally would not pay any liability. Yablon also argues that "there are important societal values inherent in maintaining a system of courts that is available and open to all sincerely brought claims for redress, even those with low probabilities of success." Id. at 105 . If there is some 
Consider, for example, a case in which $25 \%$ of juries would find for the plaintiff, while $75 \%$ of juries would not. One might disagree about whether juries tend to be biased toward the plaintiff or toward the defendant, or whether the law is biased unfairly in one direction or another. In evaluating the hypothetical, however, we should place aside these concerns, both because addressing legal substance and procedure simultaneously complicates the issues, and also because such issues are better addressed through substantive law or jury reform. Of course someone who does believe, for example, that substantive tort law is too defendant friendly may rationally conclude that a case in which $25 \%$ of juries would impose liability is one in which more than $50 \%$ of juries should impose liability. But it is most straightforward to analyze the hypothetical with an assumption that the legal system is at least minimally accurate. Specifically, we will assume that the decision that a majority of courts would reach is more likely than not the correct one. From this, the conclusion that cases with only a $25 \%$ chance of prevailing should be blocked follows straightforwardly, if only it were possible to measure this chance reliably.

It might seem that cases in which the plaintiff has a $25 \%$ chance of prevailing should simply receive $25 \%$ damages-roughly the result that one would ordinarily obtain by allowing such cases to be brought and then settled. ${ }^{18}$ This argument appeals to intuitions that disagreement is best resolved through compromise. If the substantive law allowed for partial recoveries (for example, for slight negligence), that would support such intuitions, but still only when the plaintiff had at least a $50 \%$ chance of receiving this reduced recovery. We may place aside, however, situations in which the substantive law allows for partial recoveries-for example on a ground of contributory negligencebecause we are focusing for now on whether there should be some liability, not how great liability should be. When the substantive law does not allow partial recovery, most decision makers would rule that the best answer is that the plaintiff should receive nothing. The only reason to allow a partial recovery then would be the possibility that a majority of decision makers are wrong.

value, independent of traditional economic concerns such as litigation accuracy and compensation, in keeping the court system open, then that would militate against the premise adopted here.

18. For a more comprehensive analysis of such compromise verdicts, see Michael Abramowicz, A Compromise Approach to Compromise Verdicts, 89 CALIF. L. Rev. 231 (2001), which argues that such compromises might be justifiable near the middle of the probability spectrum but not near the ends of the probability spectrum. 
A counterargument may be that the cases in which defendants wrongly must pay some settlement roughly balance out the cases in which defendants wrongly escape liability. Sometimes, a defendant may be liable, but only pay $75 \%$ damages in a settlement, because of the $25 \%$ chance that a judge or jury will wrongly find the defendant not liable. But these errors do not efficiently cancel each other out. The plaintiffs might be different. Even from a deterrence perspective, the defendants may be different too. The well-behaved defendant who is wrongly charged with liability may be different from the poorly behaved defendant wrongly absolved. The literature does suggest mechanisms for enhancing damages to compensate for a situation in which a particular defendant may have escaped payment in other circumstances, ${ }^{19}$ but rough justice across defendants will not optimize deterrence.

The strongest justification for a partial recovery may then be an insurance justification. Even though a majority of decision makers believe that the correct legal result is for no recovery, giving the plaintiff some recovery essentially provides the plaintiff with insurance against the possibility that the majority in fact reached the wrong conclusion. Perhaps if transactions costs were sufficiently low and adverse selection not a problem people would buy insurance that would award them something when courts concluded that they might be right but were probably wrong. A system that allows partial recoveries by permitting low-probability lawsuits and settlements may provide a form of such insurance.

This argument becomes weaker the lower the probability that the plaintiff would earn a recovery. Perhaps when $51 \%$ of decision makers would rule for the defendant, there is sufficient uncertainty about the law that the benefits of such an insurance function exceed the costs. When $95 \%$ of decision makers believe that the correct result under substantive law is zero recovery rather than even a small recovery, however, the insurance justification for providing that small recovery is weak. As a result, if claim screening is possible, then it will be desirable at least below some set probability threshold. Much of the analysis that follows assumes for the sake of analytical clarity that the relevant threshold is 0.5 , but the mechanism is easily extended to work for any probability threshold. The closer the probability thresh-

19. Specifically, some have suggested punitive damages inversely proportional to the probability that a defendant's actions would be detected. See Robert D. Cooter, Punitive Damages for Deterrence: When and How Much?, 40 Ala. L. Rev. 1143, 1149-53 (1989); see also A. Mitchell Polinsky \& Steven Shavell, Punitive Damages: An Economic Analysis, 111 Harv. L. REv. 869 (1998). 
old to zero, the stronger the normative case for any mechanisms that will tend to ensure that plaintiffs with cases below the threshold receive zero recovery rather than a proportionate one.

Even someone who believes that plaintiffs ideally would receive probability-adjusted recoveries might still favor mechanisms that would screen out some low-probability suits. First, there may be a fixed component to the transactions cost of litigating a case for a claimed amount of damages. That transactions cost might be worthwhile when there is a large chance that the plaintiff will receive a full or substantial recovery, but not when the lawsuit either ends up settled for a nominal recovery or goes to trial as a lottery ticket. Second, plaintiffs with very low-probability claims may be able to settle the claims for considerably more than their probability-adjusted value. If, for example, a plaintiff has a $1 \%$ chance of winning $\$ 100,000$, the defendant may be willing to pay considerably more than $\$ 1,000$ to avoid the cost of litigation. The plaintiff must bear the cost of litigation as well, so if the parties' expected litigation costs are the same, the midpoint of the bargaining range is still $\$ 1,000$ and simple models of bargaining would predict a settlement at that level. ${ }^{20}$ Often, however, the defendant's expected litigation costs will be higher, in part because the defendant cannot predict whether the plaintiff will drop the case just before trial, and so the plaintiff may be able to obtain a settlement considerably higher than the probability-adjusted value.

There is thus a theoretical case for eliminating at least lawsuits where the probability of winning is very low. Three caveats are appropriate. First, this is not a problem uniquely associated with litigation finance. The question here is simply whether, given the screening that litigation financing involves in any event, lenders can be given strong incentives not to support what they believe are low-probability claims. Later, we will consider whether the mechanism might be extended to cases in which parties ordinarily would not seek any thirdparty litigation financing. ${ }^{21}$ Second, the problem of low-probability defenses presents many of the same issues as low-probability claims. We ignore these problems for now simply because defendants are generally liquid enough to pay their litigation costs; otherwise, they would not be attractive targets for litigation. To the extent that defendants may seek third-party litigation support, the analysis in this Article extends easily. Third, the analysis assumes that the probability that the plaintiff will win is known and constant through the lawsuit. Often,

20. See, e.g., Lucian Arye Bebchuk, A New Theory Concerning the Credibility and Success of Threats to Sue, 25 J. Legal StUd. 1, 13 (1996) (adopting such an assumption).

21. See infra Part IV.B. 
the probability may initially be low as the plaintiff conducts discovery, and if discovery is successful, the probability will then rise. It may be desirable for plaintiffs to be able to bring low-probability claims that have a chance of becoming high-probability claims before trial and then to continue to pursue such cases only if supporting evidence materializes. $^{22}$

\section{B. A Single-Period Model}

To assess the effects of litigation finance, consider first a simple model in which the costs of litigation are predictable and the decision whether to finance a case is made at a single point in time. Because an existing alternative to litigation finance, at least in the United States, is contingency fee litigation, the ultimate question is which lawsuits will litigation finance support that contingency fee lawyers would reject. We can thus start with a simple model of the contingency fee, assuming for simplicity that contingency fee lawyers are risk-neutral.

Let $p$ represent the probability that the plaintiff will win the lawsuit, and assume that this is known to third parties, such as contingency fee lawyers. Let $d$ represent the fixed damages that the plaintiff would recover if the plaintiff wins the lawsuit, $c$ represent the proportion of the recovery that the contingency fee lawyer would receive, and $e$ represent the expense of litigating the suit, including the opportunity cost of the contingency lawyers' time. A lawyer will then accept a contingency fee case where the expected value of the fees more than covers the expense, that is where $p d c>e$. Thus, a contingency fee regime will screen cases where $p<e /(d c)$. Note that if we assume that $c=1 / 3$ (a common contingency fee), then the lawyer will only accept cases where $p>3 e / d$. This means that the contingency fee lawyer will accept some cases with a low $p$ because the damages are high, and will reject some cases with a high $p$ because damages are low or expenses are high.

We now introduce a litigation finance company, with the same information as the contingency fee lawyer. Let $r$ represent the interest rate on the loan that the plaintiff must repay if the plaintiff wins; this is the total interest rate over the course of the litigation, not the interest rate per year. For now, place aside the time value of money by assuming that the litigation occurs instantaneously, immediately after the loan. The finance company will loan the expenses $e$ if epr $>(1-$

22. For economic analyses of the discovery process, see Robert D. Cooter \& Daniel L. Rubinfeld, An Economic Model of Legal Discovery, 23 J. Legal Stud. 435 (1994); Bruce L. Hay, Civil Discovery: Its Effects and Optimal Scope, 23 J. Legal Stud. 481 (1994). 
$p) e$ (the expected interest received in the event the plaintiff wins is greater than the expected expenses lost in the event the plaintiff loses), assuming $d>e(1+r)$ (the damages would be great enough to allow the plaintiff to repay). It follows that litigation finance will support a lawsuit where $r>(1-p) / p$. We can consider a marginal contingency fee case, where $p=e /(d c)$ and determine the minimum interest rate that must be charged to make litigation finance possible. It can be shown that $r>(d c-e) / e$, where $d c>e$. The intuition is that the greater the contingency fee is relative to expenses, the larger the interest rate must be for litigation finance companies to support a lawsuit that contingency lawyers would reject. For example, if $e=\$ 50,000, d=$ $\$ 500,000$, and $c=1 / 3$, then contingency fee lawyers will take the case if $p>0.3$. At $p=0.3$, a litigation finance company will be willing to take the case if $r>2.33$.

In this single-period model, it is straightforward to devise a solution that would lead to greater screening by litigation finance companies. Suppose, for example, that it is deemed desirable for litigation finance companies to finance only lawsuits that the litigation finance companies believe are more likely than not to be successful. Then, because the constraint for litigation finance companies is that $r>(1-p) / p$, a rule capping $r$ at 1.0 would achieve the desired result. This is the appropriate cap, however, only under the above assumption that litigation is instantaneous. Ideally, some allowance should be made for the time value of money because the litigation finance company not only assumes a risk of defeat, but also loses interest that it could earn on the money loaned during the period of the litigation. A simple approach is to cap $r$ at 1.0 plus an ordinary (nonusurious) interest rate. For example, if an ordinary interest rate is $5 \%$ and the litigation lasts two years, then the maximum $r$ would be 1.10 . That is, the plaintiff would pay back $210 \%$ of the amount originally lent.

Of course, the formula can be applied for any desired level of screening. If, for example, it is deemed desirable for litigation finance companies to finance only lawsuits that they believe have at least a $25 \%$ chance of succeeding, then $r$ should be capped at 3.0 (plus an ordinary rate of interest). Note that this means that the most that can be repaid to the litigation finance company would be four times what was lent. As this ratio suggests, if $m$ is designated as the maximum total repayment multiple (excluding ordinary interest), then $m=e / p^{*}$, where $p^{*}$ is the target probability threshold below which we would like litigation finance companies to screen claims. Litigation finance companies and plaintiffs could still reach an agreement for a lower 
cap, and different companies could compete to provide loans to plaintiffs at the most advantageous rates.

There is a possibility that such competition might change the analysis. For example, if litigation finance companies suffer from a winner's curse,$^{23}$ then the company that makes the loan may be the one that most overestimates the probability that the plaintiff will prevail in the lawsuit. This analysis assumes that the probability of success is known to all parties or that companies rationally adjust for the winner's curse. ${ }^{24}$ Similarly, if litigation finance companies wish to increase market share by making loans, then they might be willing to make loans with negative expected value at first. The model here focuses on equilibrium behavior. On the other hand, if litigation finance companies are risk-averse, then they may be stingier about making loans. In practice, the above formula is not likely to cause companies to screen cases at exactly the desired probability threshold, but it accomplishes this goal at least crudely, and the interest rate can be adjusted to counter any observed deviation from the desired threshold.

\section{A Two-Period Model}

In practice, a simple interest rate cap is unlikely to work. The critical assumption above is that there is a single litigation period, in which the money loaned will definitely be spent and the litigation will reach a clear conclusion, with the plaintiff either winning or losing. Perhaps this assumption might be applicable in some circumstances, for example if a case is just about to go to trial and the parties have already exhausted the possibility of settlement, or under a hypothetical legal regime in which the defendant forgoes the possibility of settlement in the hope that the plaintiff will drop the lawsuit but the plaintiff does not do so. ${ }^{25}$ Some plaintiffs may have enough funding to get to trial,

23. See E.C. Capen et al., Competitive Bidding in High-Risk Situations, 23 J. Petroleum ТЕсн. 641, 643 (1971) (offering a classic illustration of the winner's curse); see also Richard H. Thaler \& William T. Ziemba, Anomalies: Parimutuel Betting Markets: Racetracks and Lotteries, J. Econ. Persp., Spring 1988, at 161 (discussing the winner's curse more generally).

24. See Otis W. Gilley et al., Uncertainty, Experience and the "Winner's Curse" in OCS Lease Bidding, 32 Mgmt. ScI. 673, 678 (1986) (arguing that rational adjustment for the winner's curse can be observed); see also Stuart E. Thiel, Some Evidence on the Winner's Curse, 78 Ам. Econ. Rev. 884, 884-86 (1988). But see Barry Lind \& Charles R. Plott, The Winner's Curse: Experiments with Buyers and with Sellers, 81 Am. Econ. Rev. 335 (1991) (illustrating that experimental subjects did not always adjust adequately for the winner's curse).

25. See David Rosenberg \& Steven Shavell, A Solution to the Problem of Nuisance Suits: The Option to Have the Court Bar Settlement, 26 Int'L Rev. L. \& ECon. 42 (2006) (proposing to allow defendants to bar settlement as a mechanism for discouraging frivolous suits). But see Ted Sichelman, Why Barring Settlement Bars Legitimate Suits: A Reply to Rosenberg and Shavell, 18 Cornell J.L. \& Pub. Pol'y 57 (2008) (offering a number of points against Rosenberg and Shavell). 
but not enough to get through trial. Permitting litigation finance subject to the above rules could ensure that plaintiffs with limited liquidity and (seemingly) sufficiently high-probability cases will be able to afford trial.

A more general approach must account for the possibility of settlement. This implies at least two periods: the first in which the parties perform some initial research and legal maneuvering, and the second in which the parties try the case if they cannot reach a settlement agreement after the first period. Of course, a still more realistic model would involve many periods of successive information acquisition and negotiation, but this simple two-period model is sufficient to show that a straight interest rate cap will not produce the desired screening behavior by litigation finance companies.

Consider a simple example where $d$, the damages if the plaintiff wins, equals $\$ 100,000$. Let $e_{\mathrm{s}}$, each party's expenses if the lawsuit is settled, equal $\$ 10,000$, and $e_{\mathrm{t}}$, each party's expenses if trial occurs, equal $\$ 50,000$. Further, suppose that $p=0.25$, so this is a case that we hope to screen out, on the simplifying assumption that 0.5 is viewed as the desirable threshold. Note that if the case were sure to go to trial, the expected return $(0.25 \times \$ 100,000)$ would not be great enough to cover the expenses $(\$ 50,000)$, so the litigation finance company would not lend the funds. If a litigation finance company were to offer a line of credit limited to $\$ 10,000$, the defendant will decline settlement, because the plaintiff's best strategy will be to drop the case.

If, however, the litigation finance company extends the line of credit to a total of $\$ 50,000$ or more, then the plaintiff has a credible threat to continue the case. The defendant's expected total cost if the case goes to trial is $\$ 50,000+(0.25 \times \$ 100,000)=\$ 75,000$. Thus, the defendant should be willing to settle for up to $\$ 75,000$. Because the loan is nonrecourse, if the interest rate is the maximum of 1.0, then the plaintiff will turn over the entire $\$ 100,000$ to the litigation finance company if the plaintiff wins, which is the same result that the plaintiff will receive if it loses. Thus, the plaintiff should be willing to settle for any amount over zero. This creates a bargaining range of between $\$ 0$ and $\$ 75,000$. Under simple economic models of settlement, cases settle at the midpoint of the bargaining range, so the settlement will be around $\$ 37,500$. The plaintiff will then pay $\$ 20,000$ of this back to the litigation finance company and keep $\$ 17,500$. Anticipating this result, the litigation finance company will have an incentive to offer the $\$ 50,000$ line of credit. Indeed, at least under these assumptions, this would provide a risk-free $100 \%$ return on the $\$ 10,000$ actually taken 
from the credit line, so competition among litigation finance companies would drive down the interest rate.

To be sure, not all examples will be this drastic, but this demonstrates that an interest rate cap will not necessarily provide adequate incentives for screening claims. It might seem that a remedy would be to prohibit agreements to extend lines of credit, allowing litigation finance only as expenses become due. The company, after all, would have an incentive to withdraw financing if the case above really were destined for trial, because trial is a losing proposition. Anticipating this, the defendant would have no incentive to settle. This might help, but lawyers may be hesitant to work with uncertain financing. ${ }^{26}$ Moreover, the incentives for a litigation finance company still might not be optimal. In considering whether to extend financing at any given time, the litigation finance company will take into account all expenses that it has previously lent. ${ }^{27}$ If it refuses further financing, those expenses will not be paid back, but they might be if further financing is offered. Although this would not change incentives in the example above, it might in a real case-especially one in which financing is awarded in small amounts over numerous points in time.

We can thus reach some tentative conclusions. First, left entirely unregulated, litigation finance can promote both high-probability and low-probability cases. The net social welfare effects depend on the distribution of cases across the probability spectrum. Because contingency fee lawyers may already take high-probability cases, and because low-probability cases may be more numerous than highprobability cases, the net welfare effects of litigation finance could be negative. Second, if financing were limited to cases that are sure to go to trial, then a simple restriction on the interest rate could prevent financing of low-probability suits. A legal regime that requires a litigation finance company that has not previously lent the plaintiff any funds to provide any needed funding for trial, combined with a legal rule preventing settlement after such financing is provided and a cap on the interest rate equal to the plaintiff's legal expenditures plus ordinary interest, would provide appropriate screening incentives. It may, however, be impractical to introduce an independent company at this stage of litigation and counterproductive to block settlement.

26. One reason for this is that the lawyer may have difficulty withdrawing from the litigation if the financing fails to materialize. See Dean R. Dietrich, Withdrawing When a Client Doesn't Pay, Wis. LAw., Sept. 2005, at 20 (noting that a lawyer in this situation may need to obtain a tribunal's permission to withdraw, and that the tribunal may decline such permission).

27. These are not sunk costs, because of the possibility that these loans might still be paid back. 
Without this combination of rules, litigation finance companies will sometimes be willing to finance cases in which the expected probability of winning is low, if they expect to be able to settle these cases.

\section{A Fee Limitation Mechanism for Litigation Finance}

The challenge remains to devise a mechanism that will encourage litigation finance companies to lend money only for cases that have a high probability of winning if the cases are actually tried. The mechanism must work ex ante even when there is some chance that the case can be settled. No mechanism can be perfect, because what matters is the probability estimate of the litigation finance company, and in a realistic model, the company's estimate of the probability of winning may deviate from the actual probability. But encouraging the lender to screen based on its probability assessment should improve results if the lender's estimates are reasonably accurate. Moreover, if the lender's estimates are noisy, the appropriate response is to lower the target probability threshold rather than to allow all suits.

This Part describes a simple mechanism that can achieve these objectives, building on the simple interest rate cap discussed in Part II. The principal extension is to impose the fee limitation for settlements as well, in proportion to the plaintiff's success in the litigation. Thus, if the plaintiff received in settlement only $50 \%$ of the damages they would have received if a court had found liability, the fee limitation would be half as great as if the plaintiff prevailed at trial and received those damages, assuming constant legal expenses. There are two key challenges that we must overcome to allow this to work. First, we must provide a mechanism that gives the plaintiff, perhaps along with other parties, incentives to accurately estimate the damages that the plaintiff would receive if successful. Second, we must guard against the danger that before the damages estimate is obtained, the parties will have incentives to reach a collusive nuisance settlement with a low damages estimate.

\section{A. Addressing Settlements and Partial Victories}

Conceptually, adjusting the fee limitation mechanism to address partial victories is simple. Let us suppose that the plaintiff receives, in settlement or at trial, $x \%$ of what might be seen as a complete victory for the plaintiff. The maximum fee the lender could charge would be capped at $x \%$ of what the cap otherwise would be. Suppose again that the target probability, below which we would like litigation finance companies to refuse to extend loans, is $p^{*}$. Then, we can set the maxi- 
mum repayment multiple $m$ at $x e / p^{*}$, plus ordinary interest. A lender will be willing to lend $e$ only when $E(x) e / p^{*}>e$, and thus $E(x)>p^{*}$, i.e. where the expected value of $x$ is greater than the target probability. This mechanism succeeds at inducing the litigation finance company to lend only if it expects that the recovery proportion exceeds the probability threshold. A case that settles at $25 \%$ of damages is a case in which the plaintiff has approximately a $25 \%$ chance of winning; this mechanism thus at least crudely optimizes incentives for any given desired probability level.

There is, however, a rub. To determine $x$, we need to have a sense of what would be a complete victory for the plaintiff. If the plaintiff were making the demand without any intervention by the litigation finance company that had lent it financing, then the plaintiff's incentive would be to make an unrealistically high damages request, because the plaintiff would want to decrease the fee that it must pay. It thus makes more sense to allow the litigation finance company to have some role, for example, by requiring a specific damages request as a condition of the contract. The litigation finance company may well be willing to reduce its allowable fee by allowing the plaintiff to make a high damages request, but this is not a problem, since it suggests that the fee limitation is unnecessary.

If, however, the litigation finance company has a role in making the demand, we must worry that the litigation finance company will insist on an unrealistically low damages level to increase $x$ and thus the allowable fee. The litigation system therefore must incorporate additional rules that discipline the plaintiff's demand so that the plaintiff, working with the litigation finance company, will not have incentives to announce an unrealistically low level. It might seem that an appropriate solution would be for the defendant to have the option of settling the case at the demand. The goal, however, is for the plaintiff to announce the damages that it would expect if it prevails on a liability claim, not a fair settlement level. Suppose, for example, that $p=0.25$ and $d=\$ 100$. The plaintiff could safely announce a demand somewhat over $\$ 25$, and this would make a settlement for $\$ 25$ appear to be largely a complete victory for the plaintiff. This would mean that the fee limitation would be set too high, and litigation finance companies would have weak incentives to screen claims.

A more promising approach might be to cap damages at the announced demand in the event that the plaintiff wins. The plaintiff then would not want to select an unrealistically low demand, because doing so would limit the amount that the plaintiff could receive in the event of a win. While this would have appropriate incentive effects in 
generating realistic demands, the consequences of the rule might be unduly harsh. Suppose, for example, that if the plaintiff prevails on liability, there is a $75 \%$ chance of $\$ 100$ in damages and a $25 \%$ chance of $\$ 200$ in damages. The plaintiff and litigation finance company might simply decide to announce a $\$ 100$ demand to increase the maximum fee that can be paid to the litigation finance company in the event of a reasonable settlement. But if there is no settlement, then this eliminates the plaintiff's chance to receive $\$ 200$ in damages, and the elimination of that chance itself will be reflected in the settlement.

Arguably, this is normatively desirable. ${ }^{28}$ Just as the goal of inducing screening by litigation finance companies is to block plaintiffs from pursuing cases with a low total probability of winning, so too it might be desirable to block a plaintiff from pursuing specific claims with a low probability of winning. But the normative desirability is less clear. Once a lawsuit is brought, the litigation costs associated with making a marginal request for extra damages are relatively low. Moreover, the chance that the plaintiff receives too much in damages in a particular case may roughly balance the chance that the plaintiff receives too little, at least in terms of deterrence effects on the defendant. This is different from the situation with liability, where, as noted above, the fact that some defendant pays too much in damages cannot balance the fact that some other defendant pays too little.

An alternative approach with a less dramatic effect is to give the defendant the option of selecting the plaintiff's demand as the damages that it will pay to the plaintiff in the event that the plaintiff prevails in the liability phase. For example, if the plaintiff announces a damages demand of $\$ 125$, the defendant could not simply settle for that amount, but could exercise an option that would mean that the damages would be set at $\$ 125$ if the plaintiff were to win. The plaintiff and litigation finance company would then have an incentive to set the demand level at a value approximately equal to the expected value of damages contingent on prevailing at the liability phase. With this approach, the demand should reflect the possibility of a high damages award by a jury that has found liability.

While this approach gives reasonable incentives, it is not perfect. The plaintiff and litigation finance company still might decide to set the demand at a slightly lower level, recognizing that the defendant will likely exercise its option, to increase the amount of payment. Moreover, if there is asymmetric information between the plaintiff

28. See infra Part IV.A.1 (modifying the mechanism developed in this Article if it is deemed desirable to block clients from pursuing low-probability litigation). 
and litigation finance company on one side, and the defendant on the other, there is a chance that the plaintiff and litigation finance company will simply make a mistake in setting a demand level and the defendant will take advantage of this. This is particularly problematic because the demand must be set at a relatively early stage of litigation. A partial remedy is to allow the plaintiff and the litigation finance company to lower the demand over time.

Still, it might distort litigation outcomes to require the plaintiff to announce a demand that gives the defendant an option to set damages and not to require the defendant to do the same. A more complicated mechanism might allow for symmetric demands. That is, the plaintiff and the defendant would both simultaneously announce damages demands, and either side would have the right to exercise the option to set damages at the level announced by the other side, which would be paid only if the plaintiff prevailed. If an option were exercised, then that value would serve to determine the fee limitation. If both sides simultaneously exercised the option, then the agreed upon damages level would be the average. The defendant will not want to announce too high a damages demand, because otherwise the plaintiff might exercise its option, but the defendant also will not want to announce too low a damages demand, because that might facilitate a litigation finance contract. The contract between the plaintiff and litigation finance company, which might be kept from the defendant, could specify some damages demand level above which the litigation finance company would withdraw its support. Of course, because the plaintiff is seeking financing and the defendant is not, the incentives of the two parties are not precisely identical, and the equilibrium may not exactly equal the average of the two parties' damages expectations, but this approach should at least give a crude estimate of the actual expected damages, and thus of $x$ in the event of a settlement.

This approach, which finds inspiration in Saul Levmore's idea of self-assessment mechanisms that give parties incentives to announce honest valuations of property rights, ${ }^{29}$ is not the only possible approach for estimating $x$. A much more conventional approach would require a court to estimate $x$. If one party voluntarily made an offer to set liquidated damages at a particular value, that might then be evidence the court could consider. Note that in any such litigation, the adversarial parties would need to be the plaintiff and the litigation finance company. The plaintiff's incentive would be to show that the

29. See generally Saul Levmore, Self-Assessed Valuation Systems for Tort and Other Law, 68 VA. L. REV. 771 (1982). 
settlement reflected a low $x$, while the litigation finance company would want to show that the settlement reflected a high $x$. This makes, of course, for an awkward litigation, as the plaintiff's incentive essentially would be to show that its case was weak. For that reason, using a conventional adversary adjudicative proceeding to estimate $x$ might be undesirable.

A separate approach, also a form of self-assessment, would require separate settlements to determine $p$ and $d$. For example, the plaintiff and defendant might first settle by agreeing that the plaintiff had a $30 \%$ chance of winning a liability finding, and then later settle by agreeing that the expected damages would be $\$ 100$. In that case, a $\$ 30$ settlement payment would be due. If the parties settled on $p$ but not $d$, a damages proceeding would be held, with the fact-finder instructed to determine damages on the assumption that liability was appropriate; if the parties settled on $d$ but not $p$, only the liability portion of a trial would be necessary. Whenever there was a settlement at $p$, then $x$ would be set to $p$ for the purpose of determining the fee limitation and the maximum payment to the lender.

The concern about this approach is that the parties might cooperate to produce unrealistic results. If the litigation finance company has no role, then the plaintiff and defendant would collude to announce a low $p$ and a high $d$. If the litigation finance company is involved in settlement negotiations, then the parties might collude to announce a high $p$ and a low $d$. This might be countered by requiring the settlements to be entered into at different times, perhaps at least some days apart. That would allow a party that received a favorable deal on the first part of the settlement not to go through on the second part. Nonetheless, there is a danger of implicit collusion, particularly if the parties (or their lawyers) are repeat players, and wish to establish a reputation for meeting their implicit commitments. As a result, this approach may not be entirely successful.

\section{B. Fee Limitation with Fee-Shifting}

The possibility of collusion illustrates a further potential vulnerability of the mechanism described above. For example, suppose that a litigation finance company is considering funding a potential plaintiff. Before filing a complaint, the litigation finance company and plaintiff might initiate negotiations with a defendant. If they can reach an agreement promptly, then they can agree to an unrealistically low $d$ and thus allow a high $x$ and a relatively high fee limitation. The defendant, of course, might not cooperate, recognizing that if it refused to cooperate then the plaintiff would choose a higher damages demand 
level, and if the litigation finance company still funded the plaintiff, it would receive only a minimal payment even if the defendant agreed to a nuisance settlement. But the litigation finance company might establish a reputation for bringing claims that have a low probability of success and pursuing them to trial, in the hope that it can convince potential defendants that it has a credible threat of bringing a case and that it is thus in their interest to cooperate with pre-settlement negotiations. Indeed, simply by entering into a finance contract with a plaintiff, the litigation finance company may credibly show that it intends to follow through on a lawsuit that would be unprofitable with a realistic, higher damages demand, and so it may be in the defendant's interest to cooperate.

It is not clear how great a danger such collusion would be. A possible remedy would be to require the damages demand to be entered into at the time of the litigation finance contract, and to not allow that number to be lowered over time. Even then, the litigation finance company might enter into informal negotiations, holding off on agreeing to a formal contract with the plaintiff. To generate nuisance settlements in such cases, the litigation finance company would need to follow through on money-losing litigation to establish a reputation as sufficiently aggressive. As a result, it may be desirable to bolster the mechanism with an additional component that would discourage such manipulation by litigation finance companies and cooperation by potential defendants who would prefer a nuisance settlement to protracted litigation. If this problem is indeed sufficiently serious, then adding a fee-shifting requirement to the fee limitation might be an effective strategy.

The fee-shifting requirement would be simple, if unconventional. The litigation finance company would be required by law to promise to pay the defendant's reasonable legal expenses if the defendant prevails at trial. Measuring reasonableness of legal expenses is not a trivial task, but it is one with which the courts have familiarity, ${ }^{30}$ and while further improvement of the courts' approaches might be achieved, that is beyond the scope of this Article. What is novel about this approach, of course, is that it is the litigation finance company, rather than the plaintiff, that is obliged to pay the defendant's reasonable legal expenses. This is equivalent to requiring the plaintiff to pay the defendant's reasonable litigation expenses, a conventional oneway fee-shifting mechanism, and requiring the litigation finance com-

30. In the process of doing so, the courts at times assess even the ex ante probability that the plaintiff had of winning a lawsuit. See, e.g., Lindy Bros. Builders v. Am. Radiator \& Standard Sanitary Corp., 487 F.2d 161, 167-68 (3d Cir. 1973). 
pany to finance this aspect of the plaintiff's expenses if it finances other expenses. The litigation finance company should be required to post a bond demonstrating proof of an ability to pay the defendant's expenses.

This fee-shifting requirement in turn would have implications for the fee limitation. Assuming that the target probability threshold is 0.5 and that the plaintiff prevails in litigation, the lender could receive back what it lent in legal expenses to the plaintiff, plus the same amount again (the plaintiff's reasonable legal expenses), plus the defendant's reasonable legal expenses, plus ordinary (nonusurious) interest. ${ }^{31}$ This fee limitation is equivalent to the interest rate cap described above, except that it is somewhat looser in that it also allows the plaintiff to pay back to the litigation finance company an additional amount equivalent to the defendant's reasonable legal expenses. Taken in isolation, the fee limitation is thus more lenient and should encourage less claim screening by litigation finance companies. But in combination with the fee-shifting requirement, this approach should produce appropriate incentives to screen out cases below the target probability threshold.

We must again adjust for partial victories, however. With a partial victory, the fee-shifting requirement would be that the lender pay (1 $x) e_{\mathrm{d}}$ to the defendant, where $e_{\mathrm{d}}$ represents the defendant's litigation expenses and $x$ represents the proportion of the damages demand that the plaintiff receives. The fee limitation-the maximum amount that could be repaid to the litigation finance company-would equal $x\left(e_{\mathrm{p}}+\right.$ $\left.\left(\left(1-p^{*}\right) / p^{*}\right)\left(e_{\mathrm{p}}+e_{\mathrm{d}}\right)\right)$, where $e_{\mathrm{p}}$ represents the plaintiff's litigation expenses, plus ordinary interest. The intuition behind this formula can be viewed by replacing $p^{*}$ and $x$ with $E(x)$ in the above formula, to examine the target marginal case for the litigation finance company. The target marginal case is the case for which the expected value of $x$ equals $p^{*}$, that is, $E(x)=p^{*}$. The formula for the maximum fee then reduces to $e_{\mathrm{p}}+(1-E(x)) e_{\mathrm{d}}$, the amount that the litigation finance company should expect to pay to litigate the dispute, including both

31. Currently, litigation finance arrangements generally set forth the total amount that the litigation finance company can receive by specifying a percentage rate on an annual or monthly basis. This has led to findings that these rates are usurious. See Grous, supra note 3, at 219-20. The approaches described here would seek to separate out the portions of the finance company's compensation, beyond return of principal, into the amount due because of the risk that the lawsuit might fail and the amount due because of the time value of money. The purpose of barring usurious rates (or, more strongly, insisting on market rates) is to prevent litigation finance companies from evading the limitation on the amount that they can receive as compensation for risk. Even separate from that, this approach may help strengthen plaintiffs' bargaining position. A high annual interest rate may force a plaintiff to take a below-market settlement. 
the plaintiff's expenditures and fee-shifting. This shows that in the target marginal case for the litigation finance company, the expected upside benefit is exactly equal to the expected downside risk. Thus, the target marginal case would in fact be the case in which the litigation finance company would be indifferent about providing financing.

This approach addresses concerns about collusion in two ways. First, it increases the cost to the litigation finance company of aggressive behavior. If the litigation finance company brings some lowprobability cases in the hope of getting a reputation for pursuing lowprobability suits and thus gaining the cooperation of defendants in other cases, then it will have to pay far more dearly in the lowprobability cases. The lower the probability that the plaintiff prevails, the more it will expect to pay. Second, the approach should decrease the defendant's willingness to enter into a nuisance settlement. A defendant that anticipates that its fees will likely be reimbursed has little to fear from litigation. A litigation finance company should thus not be able to bully such a defendant into a nuisance settlement with a collusively set damages demand. This is not, of course, proof that it will never be in a litigation finance company's interest to pursue a case below the target probability threshold in hope of obtaining a reputational benefit sufficiently large to offset the expected loss from bringing the case. That may sometimes still occur, and defendants may sometimes agree to a collusive settlement that allows a relatively high fee in other cases. Rather, the point is that fee-shifting means that a company pursuing such a strategy will expect to lose money in a higher percentage of cases because of defendants' incentives to resist nuisance settlements, thus losing more money than they otherwise would.

At some level of fee-shifting, the costs of seeking to build reputational capital by bringing low-probability cases would exceed the benefits. It is possible to vary the fee-shifting regime as long as appropriate changes are made to the fee limitation formula. For example, it might be possible to have a partial fee-shifting regime, in which the litigation finance company would pay at most half the defendant's legal costs. In that case, the fee limitation formula would substitute $0.5 e_{\mathrm{d}}$ for $e_{\mathrm{d}}$. On the other hand, it would also be possible to have a regime in which the lender would pay twice (or some other multiple) the defendant's legal costs. As long as a corresponding change in the fee limitation formula is made, the within-case incentives for the litigation finance company will continue to be to screen out cases where the plaintiff's expected probability of winning is below $p^{*}$. The necessary level of fee-shifting depends on an appraisal of 
the risk that the parties will evade the fee limitation rule for settlement by implicitly colluding as to the damages demand-that is, the risk that the across-cases reputational incentives of the litigation finance company will overwhelm the within-case incentives.

An additional possible variation is to require two-sided fee-shifting, so that the defendant must pay money to the lender if, or to the extent that, the plaintiff prevails in the litigation. To ensure that the litigation finance company would still have the appropriate incentives in screening cases, the gross payment by the defendant (without counting any offset from the payment by the litigation finance company to the defendant) would count as part of the fee subject to limitation. Two-sided fee-shifting has the advantage of being a more familiar mechanism, akin to a loser-pays law, but applying to cases that are settled as well. Moreover, the symmetry of two-sided fee-shifting ensures that the finance scheme is not systematically biased against one side or the other. A fee-shifting provision applying only to the litigation finance company would provide a systematic bias in favor of plaintiffs and would affect the value at which cases would settle. Thus, although requiring fee-shifting by the defendant as well as the litigation finance company is not essential to ensuring that the litigation finance company has appropriate incentives to screen out lowprobability cases, it may help improve the extent to which settlements reflect the probability that the plaintiff would win the litigation. While the goal of fee limitation is to screen out cases with a sufficiently low probability, there is no reason to adopt a system that would penalize plaintiffs who have a sufficiently high chance of winning.

An additional benefit of symmetrical fee-shifting is that it may improve the defendant's incentive to make a reasonable damages demand, if that aspect of the mechanism is symmetric as well. Recall that with the plaintiff and the defendant both making damages demands, the average of the two demands would serve as the basis for measuring the extent of partial victories. A defendant making a damages demand would not want to announce too high a level, because the plaintiff would then exercise the option to set any damages at that level, or too low a level, because the defendant would then expect to have to pay more in fee-shifting. To be sure, this approach may not achieve perfect symmetry; the litigation finance company and the plaintiff acting in concert may have an incentive separate from concerns about fee-shifting to announce a damages demand that is relatively favorable to the defendant, specifically that allows for a more relaxed fee limitation. A greater level of symmetry could be achieved 
only by requiring the defendant to finance the litigation through a litigation finance company.

Of course, it is possible that both parties will prefer not to have a fee-shifting mechanism or a fee limitation at all. The parties should be able, by mutual agreement, to opt out of this arrangement. This seems plausible, for example, on a relatively close case, where fee-shifting increases the risk inherent in litigation for both sides and where the defendant may recognize that the plaintiff is likely to be able to obtain financing even if the mechanism is in place. Opting out might be limited to before, or perhaps within, a short period of time after the complaint is filed, to reduce the chance of mutual evasion of the fee limitation approach. However, the addition of a fee-shifting component to the fee limitation reduces the risk of collusive settlements considerably, whether before or after the filing of the complaint, so this change may not be essential.

\section{Extensions ANd Evaluation}

\section{A. Extensions}

\section{Disputes over Damages}

There is less need to encourage claim screening when the defendant concedes liability or the legal system has produced a finding of liability and only the question of damages remains. At such a point, it has already been determined that the plaintiff has a valid claim. The only question is whether the plaintiff or the defendant is stubbornly refusing a settlement. A party might, for example, have an incentive to refuse a reasonable settlement if litigation costs are asymmetric. In general, because the plaintiff must prove damages, it seems more likely that the plaintiff will bear a greater burden of establishing damages, and thus there should be less need for encouraging screening by litigation finance companies. It is possible, however, to imagine scenarios in which screening might be beneficial. Suppose, for example, the vast majority of courts would conclude that a defendant owes a plaintiff only a nominal amount of damages, but the plaintiff pursues litigation in the hope of a long-shot large damages award. This is structurally similar to the situation in which a plaintiff brings a lowprobability case.

If such cases are of concern, the mechanism, with the addition of bidirectional fee-shifting, can be extended easily to cover disputes in which the question is not of liability, but of damages. Both the plaintiff and the defendant would make a damages demand. As before, the other side would have an option to choose the offered damages level, 
though because liability has been established or agreed to, this would now immediately resolve the case. If each side simultaneously accepted the other's damages demand, then the average between the two demands would be selected. The principal difference is that the measurement of the extent of a plaintiff's partial victory would be based on the location of the settlement figure relative to the two damages demands, rather than on the total percentage of damages received. For example, a settlement halfway between these damages demands would count as a 0.5 success level, and that would affect the fee limitation and the settlement. The use of a fee-shifting mechanism provides each side an incentive not to make an unrealistic damages demand. The success level would be constrained to be between 0 and 1 , even if the plaintiff received more than its damages demand or the defendant paid less than its damages demand.

\section{Injunctive Relief}

The possibility of injunctive relief complicates the applicability of the mechanism described here because it makes it more difficult to determine the plaintiff's degree of success, as summarized in the variable $x$ in the formulas above. It is important, however, not to exclude cases in which injunctive relief is sought along with money damages, because doing so would allow plaintiffs and litigation finance companies to easily evade the fee limitation rule. It may be more feasible to exclude cases seeking only an injunction, but for these cases too there is a danger that plaintiffs will bring claims with only a small chance of prevailing in the hope that they can achieve a cash settlement.

An alternative approach would require that the plaintiff value the injunctive relief requested. Ideally, the plaintiff should also value hypothetical partial grants of injunctive relief. There are two dangers with this approach. First, the plaintiff, in concert with the litigation finance company, might undervalue an injunction that is unlikely to be granted to reduce the applicable fee-shifting and to increase the measurement of the plaintiff's apparent success, thus relaxing the fee limitation. Second, the plaintiff might overvalue an injunction that is likely to be granted. This too would make the plaintiff appear to perform more successfully than the plaintiff in fact has performed, again reducing fee-shifting and relaxing the fee limitation.

The defendant thus must be given two options to discipline the plaintiff's valuation of injunctive relief. First, the defendant would have an option to buy out any injunctive relief granted at the price specified by the plaintiff. For example, if the plaintiff indicated that injunctive relief would be worth $\$ 100$ to it, and the plaintiff won the 
injunctive relief, the defendant could elect to pay $\$ 100$ instead. Second, if the court refused injunctive relief, the defendant would have an option to give the plaintiff the relief it sought for the value specified. In the same example, if the plaintiff lost, the defendant could opt for the plaintiff to pay $\$ 100$ for such relief. This approach is admittedly not perfect, given the likelihood that the plaintiff has limited funds, though presumably the defendant could enforce such a contract against any funds later acquired by the plaintiff.

Once again, this mechanism could be made symmetric. The defendant could indicate its cost of injunctive relief requested, and it would have similar incentives to undervalue or overvalue this cost. The plaintiff would then be allowed to exercise an option to pay the specified amount to the defendant for the relief in the case that the plaintiff lost, or in the case that the plaintiff won, to take the amount indicated by the defendant in lieu of the injunctive relief. The average value of the plaintiff's and defendant's valuations would be used to measure the overall success of the plaintiff in the litigation.

\section{Financing in Installments}

So far, we have assumed that the decision to extend a loan is made entirely at one time. This is one possible arrangement. A litigation finance company might, for example, extend a credit line of up to $\$ 1,000,000$. If the plaintiff then uses only $\$ 100,000$, then the additional $\$ 900,000$ would be irrelevant for purposes of calculating the fee limitation. But this is not necessarily ideal. It may be beneficial for lenders to monitor lawsuits as they proceed to determine whether to give increased financing. Moreover, it might make sense to increase the target probability threshold from a low value to a somewhat higher one once more information is obtained. It may be socially worthwhile for plaintiffs to bring cases that have only a small chance of producing beneficial information for the plaintiffs in discovery, as the cases can

then proceed to trial once discovery is complete if the probability of success at trial seems sufficiently high.

Extending loans and performing screening at multiple points in time complicates the ideal rule for second and subsequent payments. The litigation finance company will recognize that if it does not provide more money, the case will end, thus depriving it of the chance of receiving a fee. In addition, under the fee-shifting rules, the lender must pay for litigation expenses that the defendant has already incurred. The company should thus be willing to lend with a lower probability of winning than it would otherwise insist upon. The simplest solution is to require the plaintiff to obtain subsequent financing from an inde- 
pendent company. This, however, has the obvious disadvantage of requiring another company to become familiar with the evidence in the case.

An alternative is to adjust the rules on the fee limitation appropriately. The adjustment is relatively straightforward. Using a subscript 0 to refer to expenses already incurred and 1 to refer to expenses incurred after the second funding decision, the fee limitation would now be $x\left(e_{\mathrm{p} 1}+\left(\left(1-p^{*}\right) / p^{*}\right)\left(e_{\mathrm{p} 1}+e_{\mathrm{d} 1}\right)\right)-e_{\mathrm{d} 0}$. There are three adjustments to the formula. First, the first expenses term, which reflects return of principal, now allows recovery only of the second installment. Second, the second expenses term similarly allows fees to be recovered based on the plaintiff's expenses and the defendant's expenses, which would need to be paid with fee-shifting, after the second installment. And third, the maximum fee is reduced by the defendant's expenses to date, since this is the amount of fee-shifting that would be due if the case ended immediately.

If the litigation has proceeded far enough, this is a significantly stricter fee limitation. Ideally, a litigation finance company would like to finance the litigation in small pieces so that it can pull back if the probability of victory falls too low, much as a venture capitalist will tend to give financing only in rounds. But with this fee limitation, there will be an incentive for a litigation finance company to finance the litigation only in relatively large chunks, or perhaps with a relatively small initial payment at an early phase and a large payment at a later phase. On the other hand, if the target probability threshold rises over time, that increase can compensate for the stricter fee limitation. A relatively simple approach then is for a relatively low $p^{*}$ for an initial investigative phase followed by a significantly higher $p^{*}$, perhaps even close to 0.5 , if the litigation finance company and plaintiff wish to pursue the litigation.

\section{Diluted Mechanism}

Some plaintiffs may need only partial financing from a litigation finance company. If this is the case, the approach can be adapted simply by multiplying the fee-shifting and fee limitation amounts by the fraction of the plaintiff's total fees paid by the lender. That is, the feeshifting and fee limitation initially would be measured in terms of the total legal fees paid by the plaintiff, but would then be adjusted based on the proportion of those fees that are paid by the litigation finance company. Note that if a plaintiff uses a contingency fee lawyer, the plaintiff's total fees would equal the contingency fee plus any additional fees paid to the contingency fee lawyer as loaned by the litiga- 
tion finance company. With this approach, contingency fees and litigation finance could be used in concert.

\section{B. Evaluation}

\section{Settlement Incentives}

So far, this Article has taken a simple fee limitation designed to encourage litigation finance companies to screen out low-probability claims and made it more robust. We have seen that a basic fee limitation rule can be adjusted so that litigation finance companies can target any specified probability. More importantly, we can give the plaintiff incentives to give an honest valuation of the damages they would receive if successful on the issue of liability, so that we can measure the extent of partial victories and restrict fees accordingly. Adding a fee-shifting component makes this approach less vulnerable to collusive manipulation. Further refinements have made the mechanism applicable in situations such as when the plaintiff has sought injunctive relief, when the only issue is of damages, or when financing is provided in stages.

With these refinements, the mechanism should enable a jurisdiction allowing limited litigation financing to enact rules that will make it generally disadvantageous for finance companies to lend money when they believe that the probability the plaintiff will win is below a certain threshold percentage. At least as to the cases that are screened out, the mechanism is likely to improve the accuracy of the judicial system, by ensuring that the defendant pays no damages in cases in which at least a threshold percentage of judges would conclude that no damages are appropriate. There will inevitably be false negatives-cases that plaintiffs will not be able to bring that in reality a majority of judges would support-but the mechanism should do more to prevent false positives than to create false negatives. If false negatives were deemed a more pressing concern, the probability threshold and thus the fee limitation could be adjusted to make false negatives less commonplace.

A remaining question, however, is how the legal system will perform in cases that are not screened out - that is, those that receive financing. A particular concern is whether the mechanism might have adverse effects on settlement. In the past, critics of litigation finance have argued that litigation finance might provide perverse incentives not to settle a case. ${ }^{32}$ In one case, a tort plaintiff refused what her

32. See, e.g., Rodak, supra note 1 , at 522 ("Litigation finance is regarded by many as an obstacle to settlement. A rational plaintiff will not settle for any amount offered by the defendant 
lawyer, who did not know that she had received financing from a litigation finance company, thought was a reasonable settlement offer. ${ }^{33}$ It later turned out that the interest rate on the loan that she had received was so high that if she had accepted the settlement offer, she would have had to return the entire amount of the settlement over to the litigation finance company. ${ }^{34}$ The concern is that with excessive interest rates, plaintiffs may have perverse incentives to refuse reasonable settlements.

A preliminary response to this concern is that it ignores the possibility that the plaintiff and litigation finance company could renegotiate their contract in favor of a lower fee. Given that the litigation finance company will already be relatively familiar with the case, the marginal cost to the company of being informed about developments since it initially lent money should be relatively low. If a settlement offer is indeed optimal from the perspective of the litigation finance company and the plaintiff - that is, it is greater than the expected value of a trial outcome, taking into account legal costs-then the plaintiff and the litigation finance company have a strong collective incentive to take the offer. As long as bargaining costs are sufficiently low, then the Coase Theorem suggests that they will renegotiate if renegotiation is necessary to make the deal attractive for both parties. Of course, renegotiation may fail on occasion, and it might be useful to require litigation finance companies to inform plaintiffs of the possibility of renegotiation, but bargaining costs should be sufficiently low that litigation finance companies will have an adequate incentive to lower fees where necessary.

Even if renegotiation were impossible, a fee limitation provision should reduce the danger that a litigation finance arrangement will discourage the plaintiff from agreeing to a settlement. A key aspect of the basic fee limitation provision developed here is that the maximum fee is tied to legal expenses actually incurred, not to the total credit line offered to the plaintiff. If, for example, a litigation finance company agrees to give the plaintiff up to $\$ 1,000,000$, but the plaintiff ends up spending only $\$ 10,000$ at the time a settlement is offered, then the

that is less than the aggregate of the principal amount advanced to her and the current interest accrued ...."). Rodak notes, however, that "the interest on the advance, which accrues while the case is pending, creates an added incentive for the plaintiff to settle (and to do so as soon as possible)." Id. at 522-23.

33. Rancman v. Interim Settlement Funding Corp., No. 20523, 2001 WL 1339487 (Ohio Ct. App. Oct. 31, 2001), aff'd, 789 N.E.2d 217 (Ohio 2003). For an excellent discussion of the case, see Susan Lorde Martin, The Litigation Financing Industry: The Wild West of Finance Should Be Tamed Not Outlawed, 10 Fordham J. Corp. \& Fin. L. 55, 59-62 (2004).

34. Martin, supra note 33, at 61-62. 
fee limitation will be based on the $\$ 10,000$ figure, not the $\$ 1,000,000$ figure. (A corollary is that litigation finance is intended solely as a vehicle for paying litigation expenses, not personal expenses.) If this were not so, the fee limitation would fail to provide the appropriate case-screening incentives, as litigation finance companies could increase their effective fees simply by offering larger credit lines. ${ }^{35}$

This approach greatly reduces the chance that a need to repay the entirety of a loan to enjoy any recovery will lead a plaintiff to turn down a settlement. Also reducing the risk is the fact that if the plaintiff accepts a low settlement relative to the damages demand, the fee limitation will be stricter and the plaintiff will not have to pay as much money. To be sure, this does not eliminate the possibility that there might be situations in which the plaintiff has an incentive to turn down a fair settlement. If, for example, the plaintiff has spent $\$ 100,000$ in legal fees and the defendant offers $\$ 200,000$, but the maximum repayment multiple is 2.0 or less, then the plaintiff will have an incentive to turn down the settlement if it cannot renegotiate the fee. Between the possibility of fee renegotiation and the fee limitation approach adopted, however, the danger of reduced settlements seems minimal.

Plaintiffs who receive funding from litigation finance companies should generally be more willing to settle a case than self-financing plaintiffs. A self-financing plaintiff will compare a settlement to the amount that the plaintiff expects to receive at trial or at a later phase in the litigation, minus the additional legal fees incurred. A plaintiff whose fees are being paid through litigation finance, however, must take into account not just the expense of litigation-i.e., the amount that will be paid to the plaintiff's lawyer-but also the additional amount that must be paid to the litigation finance company if the plaintiff prevails.

Suppose, for example, that a plaintiff receives an offer of $\$ 100,000$ shortly before trial, and the expense of trial is $\$ 25,000$. For a riskneutral self-financing plaintiff, this offer would be preferable to trial as long as the expected damages at trial are less than $\$ 125,000$. For a risk-neutral plaintiff who must pay the litigation finance company twice the amount of legal expenses (given the maximum fee with a target probability threshold of 0.5 ), however, this offer will be preferable as long as expected damages at trial are less than $\$ 150,000$. In this case, a self-financing plaintiff will be more likely to accept a settlement offer than a plaintiff who receives funding from a litigation finance company. The defendant, if it knows that the plaintiff has 
received funding from a litigation finance company, will accordingly be somewhat less generous than it otherwise would be. But litigation finance should increase the probability of reaching a settlement by increasing the parties' bargaining range.

There is one final consideration that could make cases in which a plaintiff has received litigation financing easier to settle. The litigation finance company is an independent third party that has an incentive to screen out relatively low-probability claims with the mechanism proposed above. A defendant who knows that the plaintiff has received litigation finance will then recognize that the third party believes that the plaintiff's chance of winning a finding of liability exceeds a given threshold. The defendant might not agree, of course, especially if the defendant has access to information that is unavailable to the plaintiff. But a rational defendant should adjust its estimate of the probability that the plaintiff will win at least marginally in favor of the plaintiff.

Meanwhile, the fee agreement that the plaintiff receives provides a market-based assessment of the probability that the plaintiff will prevail, especially if the plaintiff attempted to obtain financing from competing companies. That is, if the fee limitation agreed upon is lower than the maximum permissible fee, then the litigation finance company has made a concession to win the plaintiff's business. By inverting the formula for the fee limitation, one can determine the minimum success probability that the finance company attributes to the plaintiff's case. Meanwhile, the fact that other companies may have refused better deals suggests that no other company believed that the plaintiff had a higher success probability. These facts should give the plaintiff better information about how an independent third party would assess the strength of its case, and if it chooses to share this information with the defendant, then the defendant should have better information as well.

In short, independent assessments of the strength of the plaintiff's case may help provide useful information to both parties and perhaps even a focal point for settlement negotiations. This is important because cases are most likely to go to trial rather than settle when the parties are mutually optimistic about their probability of success in litigation. ${ }^{36}$ For example, the plaintiff might overestimate its chance of prevailing, and the defendant might underestimate the strength of the plaintiff's case. Only in these circumstances will it make sense for each party to refuse settlement offers from the other, despite the fact

36. See, e.g., Robert H. Gertner \& Geoffrey P. Miller, Settlement Escrows, 24 J. Legal Stud. 87, 95 (1995); Evan Osborne, Who Should Be Worried About Asymmetric Information in Litigation?, 19 InT'L Rev. L. \& Econ. 399, 400 (1999). 
that the expense of trial is likely to hurt both parties. Providing some shared information, such as third parties' independent assessments of the probability that the plaintiff will succeed, should considerably reduce the probability of such mutual optimism. Cases may fail to settle for other reasons, such as strategic bargaining that leads one or both parties to bluff about the strength of their case, but improving information may also make such bluffing more difficult, and once again improve the chance of settlement.

There is at least one important caveat, however. If a fee-shifting mechanism is included, as suggested above, it may reduce the probability of settlement. The reason is that fee-shifting exacerbates mutual optimism. If each side believes that the other is likely to end up paying its expenses, then the prospect of trial does not seem so bad. The literature on the economics of litigation has long noted this effect, ${ }^{37}$ while also noting that the prospect of fee-shifting may discourage frivolous suits and frivolous defenses. Because the defendant pays fee-shifting revenue to the litigation finance company, and because any fee-shifting in the other direction is paid by the litigation finance company, the effect should only be half as severe here as with the classic loser-pays rule. Any fee-shifting may make optimistic defendants less willing to settle, but bidirectional fee-shifting should generally make defendants with weak cases more willing to settle, and there will be no direct effect on plaintiffs' incentives.

\section{Litigation Finance Fee Limitations as Tort Reform}

Fee-shifting proposals have the same principal goal as the mechanism developed here: to discourage frivolous litigation, or more specifically, to discourage cases that are filed or pursued even though one side has only a small chance of prevailing in the litigation. How does the fee limitation approach compare to this and other methods of discouraging litigants from bringing low-probability suits and maintaining low-probability defenses? An initial problem with this question is that the mechanism described here applies only to a relatively small percentage of cases, those in which the plaintiff cannot fund its own case and must seek outside financing.

In theory, however, the mechanism described here could be mandated for all plaintiffs, at least for a portion of their financing. Indeed, with minimal adjustments, it could be mandated for all defendants as well. We have already seen that both plaintiffs and defendants may

37. See, e.g., Robert Cooter \& Thomas Ulen, Law and Economics 486 (1988); Robert Cooter \& Stephen Marks with Robert Mnookin, Bargaining in the Shadow of the Law: A Testable Model of Strategic Behavior, 11 J. Legal Stud. 225, 244-46 (1982). 
make damages demands to determine the degree to which the plaintiff has succeeded in a case. If we know how well the plaintiff has performed, then we also know how well the defendant has performed. If each side were required to obtain at least $10 \%$ of its financing from a finance company subject to the mechanism developed in this Article, then each side would have to convince a finance company that it had a relatively strong probability of winning.

The mechanism described here would then be a symmetrical approach for screening out cases at both ends of the probability spectrum-those in which the plaintiff's chance of winning is so small that the lawsuit should not be brought, and those in which it is so great that the defendant ought to concede liability and contest only damages. If each side's target probability threshold were 0.5 , then the mechanism would eliminate the vast majority of disputes about liability from the courts, essentially replacing the courts' role in determining liability with a market-based system operating in the shadow of the law for the vast majority of cases. But even more lenient thresholds, perhaps at 0.25 and 0.75 , might have a significant effect on the volume of litigation.

Consideration of this approach is relevant for two reasons. First, it effectively frames the question of how effective the fee limitation is at discouraging frivolous litigation. Second, if mandatory litigation finance for a portion of each side's expenses were in fact an effective mechanism, it might not be implausible that it could be tested in some jurisdiction. The tort reform movement has been based on the premise that there are excessive incentives for parties to engage in litigation, but critics of tort reform have pointed out legitimate weaknesses of proposed reforms. If mandatory litigation finance were superior to alternative mechanisms, then perhaps the tort reform movement should advocate it. Mandatory litigation finance is unlikely to emerge from whole cloth. But it seems plausible that the fee limitation mechanism above could be implemented in cases in which plaintiffs seek litigation finance, an already controversial practice, and that experiment could someday prompt expansion of the mechanism.

There are many alternative approaches to discouraging lowprobability claims, but for our limited purposes, we will focus on three leading approaches. The first, as noted above, is a fee-shifting mechanism. We have already shown that in some cases, a fee-shifting mechanism can increase the likelihood that parties will elect to go to trial. ${ }^{38}$ This is symptomatic of a broader problem with most fee-shifting 
mechanisms. Because the fee-shifting depends on whether the plaintiff wins or loses in litigation, a penalty will be imposed both in cases near the end of the probability spectrum and sometimes in cases near the middle of the probability spectrum, when in fact sanctions against frivolous litigation should apply only in the former cases. It is cases near the middle of the probability spectrum, for example, where it is most likely that each party will conclude that it would benefit from fee-shifting. And when a case is near the middle of the probability spectrum, the losing party, despite having had a legitimate case, not only loses the case entirely, but also must pay damages. ${ }^{39}$ This is not an issue with the fee limitation mechanism, which, depending on the probability threshold, can screen out only cases near the ends of the probability spectrum.

A second mechanism for weeding out low-probability claims is to impose penalties when a judge determines that a party has advanced a frivolous position in the litigation as a whole or on a particular motion. This is the approach taken by Rule 11 of the Federal Rules of Civil Procedure. ${ }^{40}$ This might seem to have greater potential for policing the ends of the probability spectrum, and the approach could be used to discourage financing of low-probability lawsuits, as long as a litigation finance company were obliged to pay any sanctions imposed. In practice, however, fines for frivolous claims are exceedingly rare, ${ }^{41}$ perhaps in part because Rule 11 is seen as a mechanism for imposing punishment. Perhaps judges could be encouraged to impose sanctions for a larger number of claims, but they may have little incentive to do so. Moreover, unbridled judicial discretion could lead to abuses, ${ }^{42}$ while intensive judicial review of sanctions could be expensive. The fee limitation described here attempts to serve a similar function, but it does not require the exercise of judicial discretion or a debate on whether a case or motion was frivolous.

39. A possible remedy is a fee-shifting regime that would take into account not only which party wins, but also the margin of victory. See Lucian Arye Bebchuk \& Howard F. Chang, An Analysis of Fee Shifting Based on the Margin of Victory: On Frivolous Suits, Meritorious Suits, and the Role of Rule 11, 25 J. Legal STUd. 371 (1996).

40. See generally Yablon, supra note 17 (providing a critical overview of the effectiveness of Rule 11 against frivolous litigation).

41. A typical expression of judicial attends is "[t]he Court does not take the imposition of sanctions lightly, and very rarely assesses them." Stanley v. Univ. of Tex. Med. Branch, 296 F. Supp. 2d 736, 740 (S.D. Tex. 2003).

42. See Sam D. Johnson et al., The Proposed Amendments to Rule 11: Urgent Problems and Suggested Solutions, 43 BAYLor L. Rev. 647, 649 (1991) (noting the danger that courts can use Rule 11 to "coerce and intimidate litigants and their attorneys"). 
A third approach is to impose damages caps. ${ }^{43}$ This approach has been recommended and implemented most commonly for malpractice actions. ${ }^{44}$ The analysis in this Article provides some indirect support for this approach. Perhaps there is a small chance that a rogue jury will impose a much larger damages award than other juries, ${ }^{45}$ and a plaintiff may be able to extract a settlement that takes into account some fraction of this excess amount that the vast majority of courts would reject. If large damages awards are the result of idiosyncratic decision makers rather than idiosyncratic cases in which large damages awards are merited, then this approach may make sense. But it does cap damages even for those rare cases in which a majority of courts would impose larger damages, and it thus represents, at best, a crude attempt to control aberrant decision makers. The fee limitation approach here is better tailored to the specific claim or claims at issue in a particular case.

To be sure, the fee limitation mechanism described here has its own weaknesses as a mechanism for screening out low-probability cases and defenses. First, it takes real resources for a litigation finance company to evaluate a case, and these resources will come out of the relevant litigant's pocket. Sometimes, parties might opt out. They would have incentives to do so in middle-of-the-probability-spectrum cases where it is clear that both parties will be able to obtain financing in any event, but in other cases, the third-party screening will be at least somewhat expensive. The cost might be greater in some cases than in others, specifically those that involve more unusual factual or legal issues. The question is whether the cost of this screening is worth the benefit of screening out some cases on the ends of the probability spectrum. Experimentation with the fee limitation mechanism for cases in which the plaintiff would be seeking financing anyway, and thus in which these costs are inevitable, could help provide some indication of what those costs might be.

Second, the market-based system by which litigation finance companies evaluate the merits of litigation may not be as accurate as the litigation system itself. Litigation finance companies may not have access to all the information that a court would have access to at the end of a case, and they might not have incentives to engage in much more

43. Cf., e.g., 42 U.S.C. $\$ 1981 \mathrm{a}(\mathrm{b})(3)$ (2012) (imposing damages caps in certain civil rights cases, based on the size of the defendant firm).

44. For a critical analysis of the use of damages caps for malpractice cases, see Kathryn Zeiler, Turning from Damage Caps to Information Disclosure: An Alternative to Tort Reform, 5 YALE J. Health Pol'y L. \& Ethics 385 (2005).

45. Some unexpectedly large damages verdicts are reversed on appeal. See, e.g., Liggett Grp. Inc. v. Engle, 853 So. 2d 434 (Fla. Dist. Ct. App. 2003). 
than a cursory analysis of the relevant issues, especially if only providing limited financing. On the other hand, different judges may reach different decisions, perhaps because they have different ideological views about the appropriate resolution of a case, and litigation finance companies have financial incentives in assessing probabilities to average what different courts would decide. In any event, there are likely to be relatively few mistakes (for example, cases screened out where a majority of courts would find liability), especially if the fee limitation mechanism is used only to screen out cases relatively near the ends of the probability spectrum. Once again, experimentation with a fee limitation mechanism for cases in which plaintiffs are seeking financing from litigation finance companies might help provide information about the rigor of litigation finance company examination and their accuracy in assessing cases.

\section{CONClusion}

Litigation finance is a nascent field, and with relatively few companies in the market, it is likely that companies will have their pick of claims and will tend to choose relatively high-probability ones. Success by litigation finance companies, however, will inevitably spawn market entry, especially if legal uncertainties about the permissibility of litigation finance are resolved. In equilibrium, litigation finance companies will lend money whenever they think it will be profitable for them to do so. Even if this is on the whole beneficial, there may be incentives to fund some low-probability, high-damages cases in the hope of receiving either a settlement or the possibility of a windfall at trial. This Article, however, has shown that it should be feasible to design simple mechanisms that will give litigation finance companies incentives to screen out relatively low-probability cases. These incentives can be adjusted so that only very low-probability cases are screened and to accommodate a range of procedural settings and finance company strategies. Imposition of these mechanisms is not without costs, although because litigation finance companies can be expected to perform some claim screening anyway, the marginal cost of extra review is likely to be low. If such mechanisms prove relatively effective, they might serve as a basis for restraining plaintiffs from filing low-probability claims and defendants from defending high-probability claims, even where the litigants ordinarily would not need financing. Experimentation could help establish the cost and effectiveness of litigation finance companies at screening claims when given high-powered incentives to do so. 